\title{
11. PALEOMAGNETISM OF BASALT SAMPLES, LEG 27
}

\author{
M. W. McElhinny, Research School of Earth Sciences, Australian National University, Canberra, Australia
}

Nine sections of core (four each from Sites 259 and 261 and one from Site 260) were examined for their paleomagnetic directions. At Sites 259 and 261 the downward vertical direction of the cores was known, but at Site 260 the top or bottom of the core was unknown. From each length of core as many cylinders (each $2.8 \mathrm{~cm}$ in diameter and $2.8 \mathrm{~cm}$ long) as possible were drilled and sliced, providing a total of 21 specimens for investigation.

Intensities and directions of the remanent magnetization of the specimens were measured with a 105$\mathrm{Hz}$ PAR-SM1 spinner magnetometer. A test specimen from each site was subjected to stepwise partial alternating-field demagnetization in peak fields up to 400 oe using an apparatus similar to that described by McElhinny (1966). Variations in intensity for these test samples during demagnetization are illustrated in Figure 1. The test samples show good directional stability even though the intensity decays fairly rapidly up to 400 oe. A cleaning field of 150 oe was used as that most appropriate for all specimens. Values of inclination and intensity of magnetization observed for each specimen before and after cleaning are listed in Table 1 (declination is not known since only the vertical is known).

At Site 259 all specimens are reversely magnetized, but at Site 260 polarity is indeterminate because the top of the core is unknown. The specimens from Site 261 are all normally magnetized except for the specimen from core 34 which is reversely magnetized.

Mean inclinations for each site are given in Table 1, but as only three specimens were available from Site 260 , these have been combined with results from nearby Site 261. Inclinations at Site 259 are, in general, much shallower than at the other two sites. The basalt cores are all estimated to be of Late Jurassic to Early Cretaceous age (Heirtzler et al., 1973). It is of some interest to compare these results from off western Australia with Jurassic paleomagnetic results from southeast Australia. It has always been a puzzle that Jurassic paleomagnetic results from southeast Australia (including the Tasmanian dolerites) are not compatible with the usual Australia-Antarctica relationship as determined from sea-floor spreading (Heirtzler et al., 1968) or from the fit

TABLE 1

Paleomagnetic Data from Basalt Cores, Leg 27

\begin{tabular}{|c|c|c|c|c|c|}
\hline \multirow{2}{*}{$\begin{array}{c}\begin{array}{c}\text { Sample } \\
\text { (Interval in } \mathrm{cm} \text { ) }\end{array} \\
\begin{array}{c}259-38-2, \\
107-115\end{array}\end{array}$} & Specimen & Inc. & $\begin{array}{l}\text { Intensity } \\
\left(10^{-6} \mathrm{~g}\right)\end{array}$ & Inc. & $\begin{array}{l}\text { oe } \\
\text { Intensity } \\
\left(10^{-6} g\right)\end{array}$ \\
\hline & $\begin{array}{l}\text { A } \\
\text { B }\end{array}$ & $\begin{array}{l}+59.1 \\
+58.2\end{array}$ & $\begin{array}{l}5568 \\
5646\end{array}$ & $\begin{array}{l}+61.1 \\
+60.6\end{array}$ & $\begin{array}{l}2637 \\
1927\end{array}$ \\
\hline $\begin{array}{c}259-39-1 \\
85-92\end{array}$ & $\begin{array}{l}\text { A } \\
\text { B }\end{array}$ & $\begin{array}{l}+31.7 \\
+31.3\end{array}$ & $\begin{array}{r}984 \\
1035\end{array}$ & $\begin{array}{l}+41.1 \\
+42.8\end{array}$ & $\begin{array}{l}196 \\
232\end{array}$ \\
\hline $\begin{array}{c}259-41-2 \\
131-139\end{array}$ & $\begin{array}{l}\text { A } \\
\text { B }\end{array}$ & $\begin{array}{l}+82.0 \\
+80.1\end{array}$ & $\begin{array}{l}3417 \\
3478\end{array}$ & $\begin{array}{l}+81.8 \\
+80.9\end{array}$ & $\begin{array}{l}1350 \\
1475\end{array}$ \\
\hline $\begin{array}{c}259-41-3 \\
83-93\end{array}$ & $\begin{array}{l}\mathrm{A} \\
\mathrm{B} \\
\mathrm{C}\end{array}$ & $\begin{array}{l}+10.6 \\
+18.7 \\
+21.4\end{array}$ & $\begin{array}{l}5152 \\
1956 \\
3987\end{array}$ & $\begin{array}{l}+35.4 \\
+34.5 \\
+38.7\end{array}$ & $\begin{array}{l}674 \\
622 \\
580 \\
\end{array}$ \\
\hline $\begin{array}{l}260-20-1, \\
\text { Piece No. } 5^{\mathrm{a}}\end{array}$ & $\begin{array}{l}\text { A } \\
\mathrm{B} \\
\mathrm{C}\end{array}$ & $\begin{array}{l} \pm 48.7 \\
\pm 53.7 \\
\pm 50.3 \\
\end{array}$ & $\begin{array}{l}11170 \\
12000 \\
12700 \\
\end{array}$ & $\begin{array}{l} \pm 52.4 \\
\pm 53.7 \\
\pm 62.8 \\
\end{array}$ & $\begin{array}{l}991 \\
862 \\
782 \\
\end{array}$ \\
\hline $\begin{array}{c}261-34-2 \\
121-132\end{array}$ & $\begin{array}{l}\text { A } \\
\text { B }\end{array}$ & $\begin{array}{l}+80.3 \\
+62.7\end{array}$ & $\begin{array}{l}920 \\
944\end{array}$ & $\begin{array}{l}+82.3 \\
+80.6\end{array}$ & $\begin{array}{l}361 \\
346\end{array}$ \\
\hline $\begin{array}{c}261-35-4 \\
87-97\end{array}$ & $\begin{array}{l}\text { A } \\
\text { B } \\
\text { C }\end{array}$ & $\begin{array}{l}-67.5 \\
-61.7 \\
-58.5\end{array}$ & $\begin{array}{l}3102 \\
3836 \\
4392\end{array}$ & $\begin{array}{l}-60.8 \\
-62.8 \\
-64.8\end{array}$ & $\begin{array}{l}142 \\
211 \\
243\end{array}$ \\
\hline $\begin{array}{c}261-37-1 \\
105-115\end{array}$ & $\begin{array}{l}\mathrm{A} \\
\mathrm{B}\end{array}$ & $\begin{array}{l}-62.1 \\
-65.6\end{array}$ & $\begin{array}{l}3706 \\
3233\end{array}$ & $\begin{array}{l}-60.4 \\
-63.4\end{array}$ & $\begin{array}{l}605 \\
600\end{array}$ \\
\hline $\begin{array}{c}261-39-1, \\
23-35\end{array}$ & $\begin{array}{l}\mathrm{A} \\
\mathrm{B}\end{array}$ & $\begin{array}{l}-71.1 \\
-84.7 \\
\end{array}$ & $\begin{array}{l}1971 \\
1962 \\
\end{array}$ & $\begin{array}{l}-72.5 \\
-72.9 \\
\end{array}$ & $\begin{array}{l}700 \\
727 \\
\end{array}$ \\
\hline $\begin{array}{l}\text { Note: Mean } 259 \\
\text { Inc. }=56.3 \text { at } \\
+261, N=12, \mathrm{I}\end{array}$ & $\begin{array}{l}V=9, \text { Inc. }= \\
\text { oe; Mear } \\
=65.8 \pm 2.7\end{array}$ & $\begin{array}{l}0 \pm 6.3 \\
61: N \\
150 \text { oe }\end{array}$ & $\begin{array}{l}150 \\
\text { Inc. }=6\end{array}$ & $\begin{array}{l}\text { Mean } \\
8 \text { at } 1\end{array}$ & $\begin{array}{l}N=3 \\
\text { oe } ; 260\end{array}$ \\
\hline
\end{tabular}




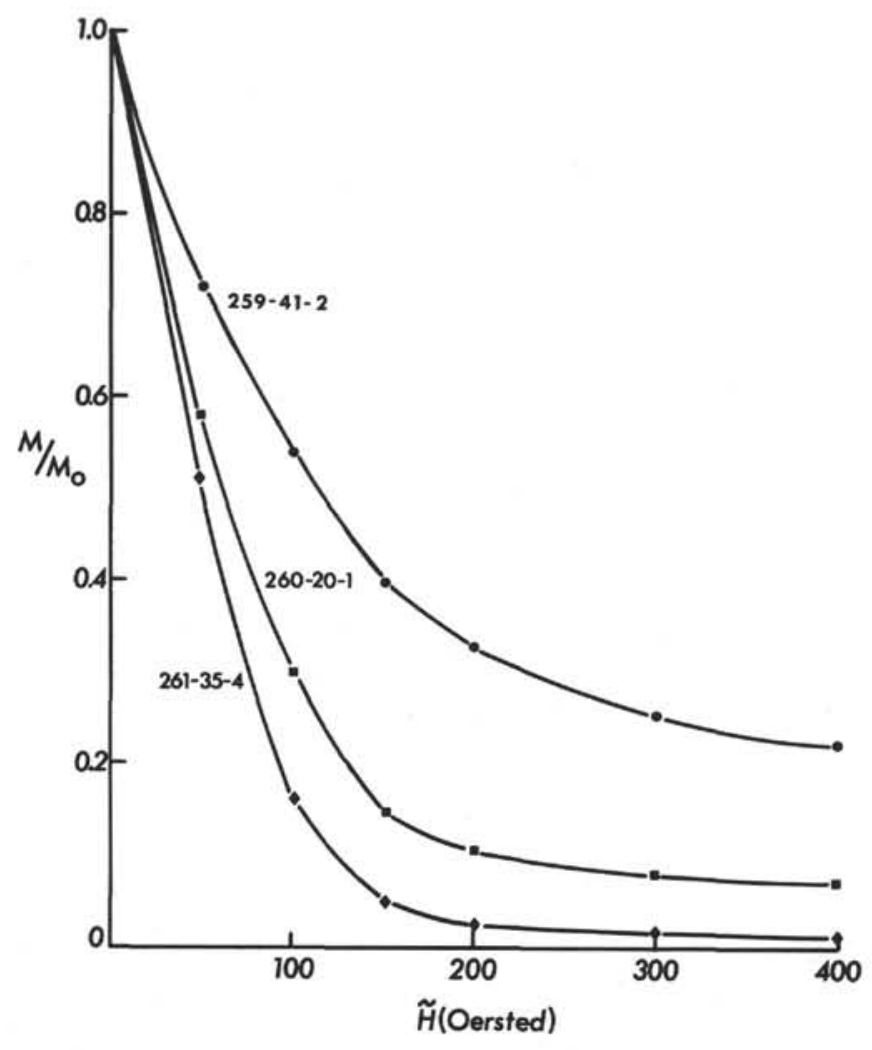

Figure 1. Alternating field demagnetization curves for test specimens from Sites 259, 260, and 261

of the coastlines (Sproll and Dietz, 1969; Smith and Hallam, 1970). The point is illustrated in Figure 2, in which it can be seen that the pole from the Jurassic Ferrar dolerites of Antarctica does not agree with Australian Jurassic pole when the two continents are reconstructed. Since the Ferrar and Tasmanian dolerites are not only of the same age (McDougall, 1961; 1963) but also belong to the same geochemical province (Compston et al., 1968), the inconsistency is further emphasized. On the other hand, the Jurassic Ferrar pole from Antarctica is quite consistent with other Gondwanic poles of the same age, so it is the Australian results that are anomalous (McElhinny, 1973).

Using the mean inclinations from the basalt cores, the colatitudes of the site locations can be determined and an arc of a circle with radius equal to the colatitude determines possible positions on which the corresponding pole must lie. In Figure 2 it can be seen that the colatitude at Site 259 is compatible with the Ferrar pole from Antarctica whereas the colatitude at Sites 260 and 261 is compatible with the Australian Jurassic pole. Although this does not help resolve the problem, the result suggests that the "anomalous" Jurassic poles of southeast Australia are not just restricted to that region but may also be found in parts of western Australia.

\section{REFERENCES}

Compston, W., McDougall, I., and Heier, K. S., 1968. Geochemical comparison of the Mesozoic basaltic rocks of Antarctica, South Africa, South America and Tasmania: Geochim. Cosmochim. Acta, v. 32, p. 129-149.

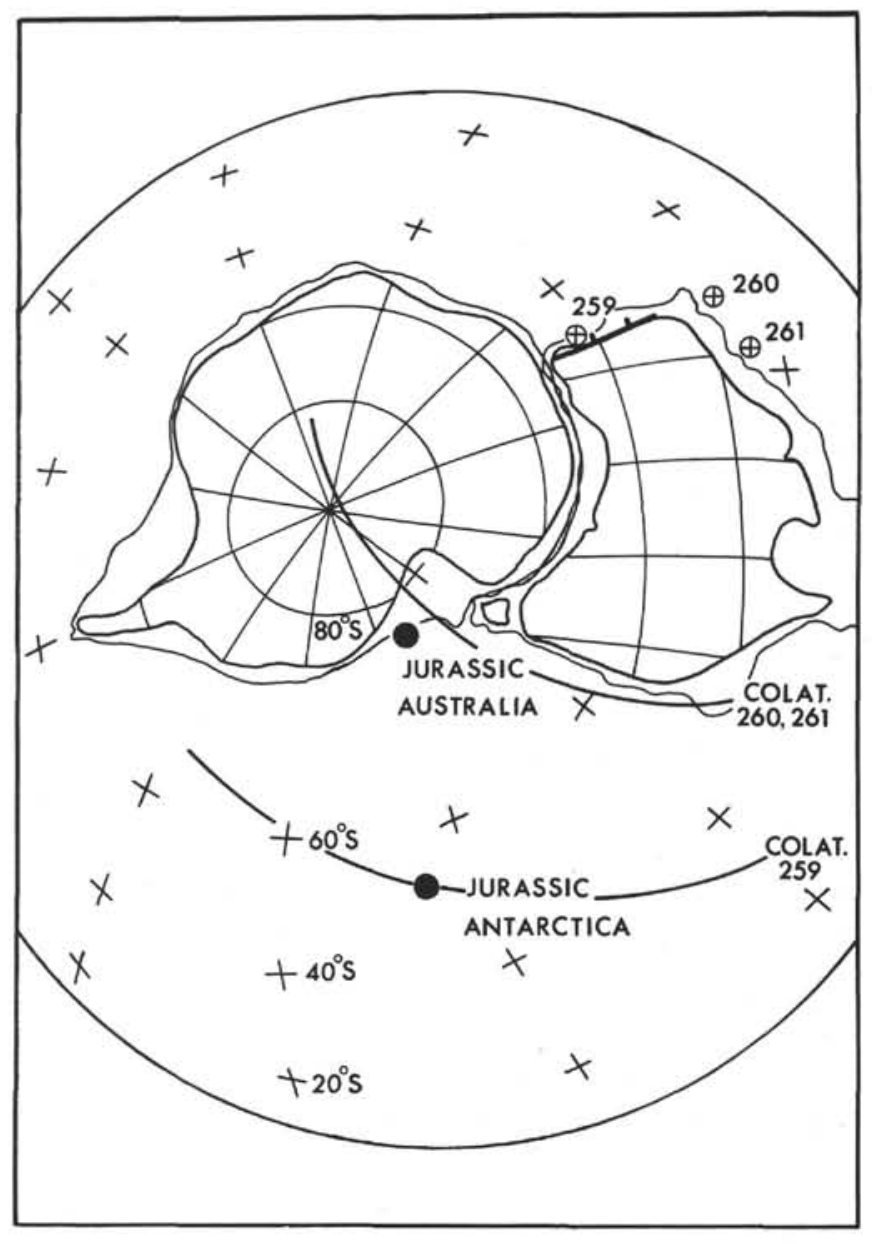

Figure 2. Comparison of the Jurassic poles of Australia and Antarctica in their reconstructed positions. The arcs of the circles are the colatitudes (and define the location of possible pole positions) drawn from Site 259 and Sites 260 and 261 combined.

Heirtzler, J. R., Dickson, G. O., Herron, E. M., Pitman, W. C., III, and Le Pichon, X., 1968. Marine magnetic anomalies, geomagnetic field reversals and motions of the ocean floor and continents: J. Geophys. Res., v. 73, p. 2119-2136.

Heirtzler, J. R., Veevers, J. J., Bolli, H. M., Carter, A. N., Cook, P. J., Krasheninnikov, V. A., McKnight, B. K., Proto-Decima, F., Renz, G. W., Robinson, P. T., Rocker, K., and Thayer, P. A., 1973. Age of the eastern Indian Ocean floor: Science, v. 180, p. 952-954.

McDougall, I., 1961. Determination of the age of a basic igneous intrusion by the potassium-argon method: Nature, v. 190, p. $1184-1186$

1963. Potassium-Argon age measurements on dolerites from Antarctica and South Africa: J. Geophys. Res., v. 68 , p. $1535-1545$.

McElhinny, M. W., 1966. An improved method for demagnetizing rocks in alternating magnetic fields: Roy. Astron. Soc. Geophys. J., v. 10, p. 369-374.

1973. Palaeomagnetism and plate tectonics: Cambridge, (Cambridge University Press).

Smith, A. G. and Hallam, A., 1970. The fit of the southern continents: Nature, v. 225, p. 139-144.

Sproll, W. and Dietz, R. S., 1969. Morphological continental drift fit of Australia and Antarctica: Nature, v. 222, p. 245248. 